\title{
UPAYA MENINGKATKAN KINERJA PEMASARAN PADA UMK DURIAN JATUHAN DI DAERAH BANTEN
}

\author{
Oleh: Reni Febriani ${ }^{1)}$ Achmad Irfan Firdaus ${ }^{2}$ \\ Universitas Banten Jaya \\ Serang, Indonesia \\ renifebriani@unbaja.ac.id
}

\begin{abstract}
This study aims to determine the effect of market orientation and environmental adaptability through product innovation on marketing performance. The samples studied were durian MSME actors (in the form of durian or durian processed) that were registered with the Banten Durian Entrepreneur Group (KPDB) with 70 businessmen in the Serang, Cilegon, Pandeglang and Lebak regions. Sources of research data are obtained from online questionnaires using google forms tools that are distributed via the whatsapp media group. Data processing uses the Structural Equation Model (SEM) approach with Smart PLS 3.0 Software. The results showed that market orientation and environmental adaptability didn't have a positive effect on marketing performance, environmental adaptability didn't have a positive effect on product innovation, market orientation have a positive effect on product innovation, and product innovation have a positive effect on marketing performance. From the results of this study indicate that MSEs have not been consistent in improving marketing performance, because durian is still classified as seasonal fruit and the price is high when it is out of season.
\end{abstract}

Keywords: marketing performance, market orientation, environmental adaptability, product innovation.

PENDAHULUAN

Usaha Mikro Kecil (UMK) yang tengah berkembang pesat saat ini, dan merupakan segmen pasar terbesar dalam pertumbuhan ekonomi nasional. Begitupula dengan pelaku UMK durian yang sampai saat ini terus eksis dan berkembang dalam melakukan kegiatan usaha bisnisnya.

Kendala yang dialami atau dihadapi oleh UMK buah durian dalam menjalani bisnisnya yaitu umur kematangan durian yang relatif singkat. Durian jatuhan (matang dipohon) memiliki umur maksimal 3 hari. Apabila lewat dari itu maka durian akan terkelupas dan terkontaminasi daging buahnya dengan udara, menyebabkan buah cepat asam, lembek dan busuk. Mengingat hal tersebut maka diperlukan strategi pemasaran yang baik untuk menjual durian jatuhan agar cepat habis sebelum terjadinya pembusukan pada durian tersebut. Untuk memperpanjang umur penjualan durian, tidak sedikit para UMK ini memilih durian petikan (matang luar pohon) karena umur 
PROGRESS

Jurnal Pendidikan, Akuntansi dan Keuangan

Universitas Banten Jaya pemasaran menjadi lebih panjang sekitar 1 minggu, namun kualitas rasa dan aroma durian ini tidak lebih baik dari durian jatuhan. Sehingga dari kualitas buah durian pun akan menghambat dalam proses pemasarannya. Untuk mengadaptasi permasalahan tersebut umur dari penjualanan buah durian yang sangat singkat maka ada beberapa inovasi durian yang telah dilakukan sampai tersedia dalam bentuk frozen (pembekuan). Durian yang telah dibekukan mempunyai ketahanan hingga 6 bulan asalkan pada tahap proses penyimpanan atau pembekuannya dilakukan dengan baik dan sesuai dengan ketentuan.

Hal menarik yang menjadi perhatian pebisnis olahan Durian adalah para pelaku UMK ini tak terbatas oleh kalangan tertentu saja, akan tetapi dari semua kalangan, mulai dari wirausaha, pegawai negeri, pegawai swasta, anak kuliahan, hingga ibu rumah tangga turut serta dalam menjalankan usahanya. Berbeda dengan penjual durian utuh yang biasa kita jumpai di pasar tradisional atau di pinggir jalan, biasanya mereka adalah para pedagang wirausaha musiman sesuai dengan waktu musim durian.

Dalam menjalankan usahanya, UMK Durian memiliki berbagai pasang surut. Contohnya yang terjadi pada salah satu UMK di daerah Serang, yaitu Kedai Duren
Woke Serang seperti terlihat pada Gambar 1. Dari gambar 1 dibawah ini, dapat diketahui bahwa omset penjualan di sepanjang tahun 2018 terhitung Januari hingga November 2018 menunjukkan angka yang fluktuasi (pasang surut).

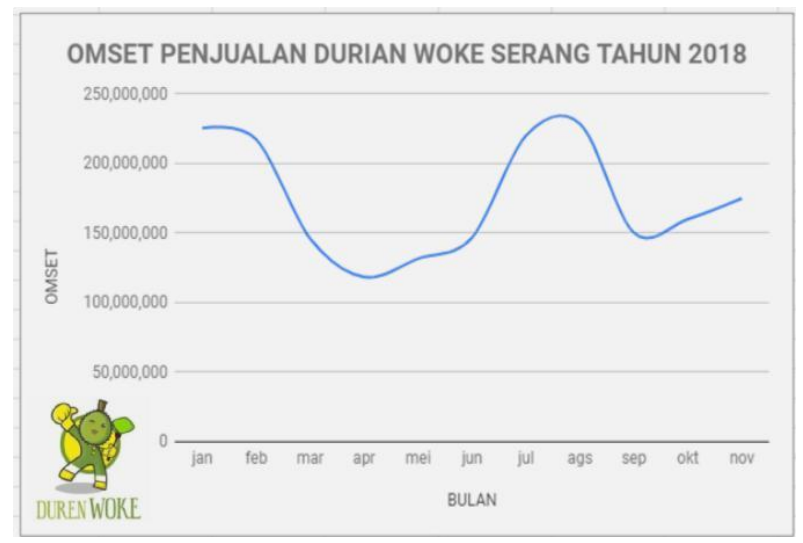

Gambar 1. Grafik omset penjualan Kedai Duren Woke Serang 2018.

Pencapaian omset yang tinggi (>200 juta) berada pada musim panen raya pertama seperti di bulan Januari dan Februari 2018, serta pada musim panen raya pertengahan seperti di bulan Juli dan Agustus 2018. Sedangkan pada bulanbulan setelahnya (diluar panen raya) omset penjualan Kedai Duren Woke Serang mengalami penurunan dikarenakan pengandaan buah durian yang sedikit.

Hal ini menunjukkan bahwa faktor lingkungan (musim) amat sangat berpengaruh terhadap omzet penjualan para pebisnis durian. Saat buah durian tidak berada pada masa panen raya, beberapa pebisnis mengalami penurunan 
PROGRESS

Jurnal Pendidikan, Akuntansi dan Keuangan Universitas Banten Jaya pendapatan. Buah yang langka, harga durian yang mahal, sehingga berpengaruh ke daya beli masyarakat yang rendah, menjadi alasan menurunnya omset penjualan mereka. Para UMK Durian ini harus dituntut untuk kreatif dan inovatif dalam menjalankan bisnisnya agar roda bisnis akan terus berjalan, dan minimal pendapatan yang didapat pelaku usaha durian terus stabil dan tidak turun drastis.

Berdasarkan fenomena bisnis, terjadi penurunan kinerja pemasaran pada UMK durian, sehingga menjadi bekal bagi penulis untuk merumuskan masalah tentang bagaimana UMK durian dapat meningkatkan kinerja pemasaran melalui peningkatan orientasi terhadap pasar dan adaptabilitas lingkungan bisnis yang berpengaruh terhadap inovasi produk.

Adapun tujuan dilakukan penelitian ini adalah untuk :

1. Mengetahui pengaruh orientasi pasar terhadap kinerja pemasaran pada UMK durian di daerah Banten

2. Mengetahui pengaruh adaptabilitas lingkungan terhadap kinerja pemasaran pada UMK durian di daerah Banten.

3. Mengetahui pengaruh orientasi pasar terhadap inovasi produk pada UMK durian di daerah Banten.

4. Mengetahui pengaruh lingkungan terhadap produk inovasi pada UMK durian di daerah Banten.
5. Mengetahui pengaruh inovasi produk terhadap kinerja pemasaran pada UMK durian di daerah Banten.

Orientasi pasar merupakan ukuran perilaku dan aktivitas yang mencerminkan implementasi konsep pemasaran (Tjiptono, 2015). Sedangkan Uncles (2005) mengartikan orientasi pasar sebagai satu proses dan aktivitas yang berhubungan dengan penciptaan dan pemuasan pelanggan dengan cara terus menilai kebutuhan dan keinginan pelanggan. Penerapan orientasi pasar akan membawa peningkatan kinerja bagi perusahaan tersebut. Orientasi pasar sangat efektif dalam mendapatkan dan mempertahankan keunggulan kompetitif yang dimulai dengan perencanaan dan koordinasi dengan semua bagian yang ada dalam organisai untuk memuaskan kebutuhan dan keinginan konsumen. Oleh karena itu orientasi pasar harus menekankan analisis kebutuhan dan keinginan target pasar secara efisien dan efektif dibandingkan dengan pesaingnya dalam usaha untuk mencapai keunggulan bersaing.

Dengan demikian dapat disimpulkan bahwa orientasi pasar menjadi bagian penting bagi sebuah perusahaan dalam meningkatkan persaingan global dan perubahan kebutuhan pelanggan dimana sebuah perusahaan menyadari bahwa mereka harus selalu dekat dengan pasar 
PROGRESS

Jurnal Pendidikan, Akuntansi dan Keuangan Universitas Banten Jaya untuk selalu mengetahui apa yang menjadi kebutuhan pelanggannya dengan cara terus menilai kebutuhan dan keinginan pelanggan. Orientasi pasar merupakan budaya bisnis dimana suatu organisasi mempunyai komitmen untuk terus berkreasi dalam menciptakan nilai unggul bagi pelanggan. Orientasi pasar yang kuat di perusahaan bisa memberikan penawaran dan memberikan kepuasan yang lebih baik kepada pembeli serta perusahaan akan memperoleh hasil yang lebih besar atas penawaran yang diberikan.

Pengambilan keputusan untuk mencapai tujuan jangka pendek maupun tujuan jangka panjang, pemasar perlu melakukan analisis terhadap perubahan lingkungan. Lingkungan menyajikan ketidakpastian karena sifatnya yang selalu berubah-ubah dimana pemasaran itu dilakukan. Setiap bisnis berusaha memelihara kelangsungan hidup perusahaan, mencapai pertumbuhan, meningkatkan kesejahteraan dan sabagainya, maka perusahaan harus melakukan penyesuaian diri dengan kondisi lingkungan (Hasan, 2013).

Lingkungan pemasaran adalah pelaku dan kekuatan diluar pemasaran yang mempengaruhi kemampuan manajemen pemasaran untuk membangun dan mempertahankan hubungan yang berhasil dengan pelanggan sasaran. Perusahaan harus terus melakukan pengamatan secara terus menerus dan beradaptasi dengan lingkungan yang bersifat kompleks dan terus berubah-ubah, dengan mempelajari lingkungan perusahaan dapat menyesuaikan strategi perusahaan untuk memenuhi tantangan dan peluang pasar yang baru, (Kotler, 2014).

Menurut Suryani (2008), Inovasi dalam konsep yang luas sebenarnya tidak hanya terbatas pada produk saja, akan tertapi inovasi dapat berupa ide, cara-cara ataupun obyek yang dipersepsikan oleh seseorang sebagai sesuatu yang baru. Inovasi juga sering dugunakan untuk merujuk pada perubahan yang dirasakan sebagai hal yang baru oleh masyarakat yang mengalami. Namun demikian, dalam konteks pemasaran dan konteks perilaku konsumen inovasi dikaitkan dengan produk atau jasa yang sifatnya baru. Dalam hal ini produk baru merujuk pada produk yang memang benar-benar belum pernah ada sebelumnya di pasar dan yang belum pernah ditemui konsumen di pasar.

Kata inovasi dapat diartikan sebagai "proses" atau "hasil" pengembangan dan atau pemanfaatan atau mobilisasi pengetahuan, keterampilan (termasuk keterampilan teknologis) dan pengalaman untuk menciptakan atau memperbaiki produk, proses yang dapat memberikan nilai yang lebih berarti. Menurut Sutarno 
PROGRESS

Jurnal Pendidikan, Akuntansi dan Keuangan

Universitas Banten Jaya
(2012), inovasi adalah transformasi pengetahuan kepada produk, proses dan jasa baru, tindakan menggunakan sesuatu yang baru. Sedangkan menurut Mitra pada buku tersebut dan pada halaman yang sama, bahwa inovasi merupakan eksploitasi yang berhasil dari suatu gagasan baru atau dengan kata lain merupakan mobilisasi pengetahuan, keterampilan teknologis dan pengalaman untuk menciptakan produk, proses dan jasa baru.

Kinerja perusahaan merupakan ukuran keberhasilan dari suatu perusahaan yang diukur setiap jangka waktu yang telah ditentukan. Hasil ini dapat dikatakan sebagai nilai dari setiap aktivitas yang disusun dan dilaksanakan untuk dapat mengidentifikasi apakah strategi yang dibuat dan pelaksanaannya adalah tepat atau malah sebaliknya.

Prakosa (2005) mendefinisikan kinerja sebagai sukses produk baru dan pengembangan pasar, dimana kinerja perusahaan dapat diukur memalui pertumbuhan penjualan dan porsi pasar.

Ferdinand (2014) menyatakan bahwa kinerja pemasaran merupakan konsep untuk mengukur prestasi pasar suatu produk, dimana setiap perusahaan berkepentingan untuk mengetahui prestasi pasar dari produk-produknya. Kinerja pemasaran merupakan konstruk yang umum digunakan untuk mengukur dampak dari sebuah strategi perusahaan, sedangkan kinerja perusahaan dipengaruhi oleh tiga hal antara lain efektifitas perusahaan, pertumbuhan penjualan dan kemampuan memperoleh laba.

Penelitian terdahulu tentang pengaruh orientasi pasar terhadap kinerja pemasaran menunjukkan belum ada konsistensi pengaruh antar variabel tersebut. Misalnya pada penelitian yang dilakukan oleh Anshar (2016), Haryani (2015), dan Setyawati, dkk (2013) bahwa orientasi pasar belum dapat mempengaruhi kinerja pemasaran. Penelitian ini sangat bertentangan dengan penelitian yang dilakukan oleh Dharmana, dkk (2017) yang menyatakan bahwa terdapat pengaruh yang signifikan antara orientasi pasar terhadap kinerja pemasaran. Selaras dengan penelitian yang dilakukan Ida Tri, dkk (2015) bahwa semakin tinggi pengaruh orientasi pasar maka akan semakin tinggi kinerja pemasaran produk yang dihasilkan.

Berdasarkan uraian diatas maka hipotesis yang diajukan dalam penelitian ini sebagai berikut :

H1: Semakin tinggi pengaruh orientasi pasar maka akan semakin tinggi kinerja pemasaran produk yang dihasilkan.

Penelitian yang dilakukan oleh Charlina dkk (2016) di PT. BPR Prisma 
PROGRESS

Jurnal Pendidikan, Akuntansi dan Keuangan Universitas Banten Jaya
Dana Amurang menyatakan bahwa ada pengaruh yang signifikan positif antara lingkungan pemasaran terhadap kinerja pemasaran. Lingkungan pemasaran merupakan suatu hal yang penting dalam perusahaan untuk melihat keadaan dan peluang yang ada disekitar atau diluar perusahaan.

Penelitian serupa yang dilakukan oleh Sendhang (2012) pada UMK kerajinan kulit di Tanggulangin mengemukakan bahwa faktor lingkungan dapat mempengaruhi kinerja pemasaran secara signifikan. Pengrajin usaha kecil perlu untuk selalu dapat mengantisipasi adanya perubahan lingkungan industri dengan menetapkan strategi pemasaran yang tepat sehingga menghasilkan kinerja pemasaran yang baik. Sehingga pengrajin usaha kecil tetap dapat bersaing dan dapat menjaga keberlangsungan hidup usahanya.

Dari para peneliti sebelumnya yg telah dilakukan, maka didapat hipotesis sebagai berikut:

$\mathrm{H} 2$ : Semakin tinggi adaptabilikas lingkungan yang dilakukan, maka akan semakin tinggi kinerja pemasaran.

Penelitian yang dilakukan oleh Dharmana, dkk (2017) pada UMK kerajinan perak di Desa Celuk Kabupaten Gianyar menemukan bahwa orientasi pasar berpengaruh positif signifikan terhadap inovasi produk, Hal tersebut berarti bahwa semakin baik UMK kerajinan perak memahami pasar melalui pendekatan orientasi pelanggan dan pesaing, maka kinerja pemasaran akan semakin meningkat.

Penelitian lainnya dilakukan oleh Anshar (2016), Orientasi pasar yang menitikberatkan pada orientasi terhadap pelanggan di PT Telkom memiliki hubungan dan bepengaruh positif terhadap derajat inovasi layanannya. Begitupula dengan penelitian yang dilakukan oleh Ida Tri, dkk (2015) pada UMK di Kota Malang menyatakan bahwa orientasi pasar berpengaruh positif signifikan terhadap inovasi produk.

Merujuk pada uraian diatas maka hipotesis yang diajukan dalam penelitian ini sebagai berikut :

H3: Semakin tinggi pengaruh orientasi pasar, maka semakin tinggi pula inovasi produk yang akan dilakukan.

1.Pengaruh adaptabilitas lingkungan terhadap inovasi produk

Lingkungan bisnis selalu berubah, hal ini bisa terjadi karena perubahan

peraturan, teknologi, permintaan konsumen dan strategi. Cepatnya perubahan yang terjadi dalam lingkungan perusahaan menuntut para pengambil keputusan untuk menaruh perhatian pada lingkungan persaingan dan merespon setiap perubahan (Janti dkk, 2013). 
Penelitian yang dilakukan oleh Janti, dkk (2013) pada UMK di Jawa Tengah memberikan hasil bahwa Lingkungan berpengaruh secara signifikan terhadap inovasi. Artinya, meningkatnya pengaruh lingkungan akan menyebabkan meningkatnya inovasi. Hasil penelitian sebelumnya pernah juga dilakukan oleh Khamidah (2005) pada UMK keramik di Bantul Yogyakarta, bahwa lingkungan mempunyai pengaruh signifikan terhadap inovasi produk.

Namun, pendapat yang berbeda diungkapkan oleh Sukarno (2009) dalam penelitiannya pada UMK di daerah Sidoarjo, bahwa lingkungan tidak berpengaruh signifikan positif terhadap Inovasi. Kondisi demikian menunjukkan bahwa perubahan lingkungan perusahaan yang tercermin dari perubahan peraturan, kemajuan teknologi, perubahan permintaan konsumen yang selalu menuntut diadakan perubahan belum dapat memberikan kontribusi terhadap aktivitas inovasi produk yang tercermin dari belum adanya ide baru maupun belum adanya produk baru. Temuan dari penelitian ini bertentangan dengan penelitian yang dilakukan oleh Janti, dkk (2013) dan Khamidah (2005) bahwa lingkungan mempunyai pengaruh signifikan terhadap inovasi produk.

Dinamika lingkungan persaingan mempunyai pengaruh positif terhadap keinovativan. Oleh karenanya inovasi merupakan sebuah mekanisme perusahaan untuk beradaptasi dalam lingkungan yang dinamis. Hal ini tentunya akan merujuk pada hipotesis yang diambil dari penelitian ini sebagai berikut :

H4 : Semakin tinggi pengaruh lingkungan, maka semakin tinggi pula inovasi produk yang akan dilakukan.

Beberapa penelitian yang sudah dilakukan oleh para peneliti sebelumnya tentang pengaruh inovasi produk terhadap kinerja pemasaran, seperti Dharmana, dkk (2017), Anshar (2016), Ida Tri, dkk (2015), Janti, dkk (2013), Sukarno (2011), dan Khamidah (2005) hasil penilitian seragam menyatakan bahwa inovasi produk berpengaruh positif signifikan terhadap kinerja pemasaran. Artinya bahwa kinerja pemasaran yang dialami oleh suatu UMK / perusahaan dapat ditingkatkan dengan cara meningkatkan inovasi produk.

Berdasarkan hasil penelitian di atas maka hipotesis yang diajukan dalam penelitian ini sebagai berikut :

H5 : Semakin ditingkatkannya inovasi produk, maka kinerja pemasaran akan semakin meningkat.

Dukungan dari teoritis hasil dari telaah pustaka, pengembangan hipotesis, 
PROGRESS

Jurnal Pendidikan, Akuntansi dan Keuangan

Universitas Banten Jaya dan penelitian terdahulu, maka penulis dapat menggambarkan hubungan dari variabel independent, dalam hal ini adalah Orientasi pasar (X1) dan Adaptabilitas Lingkungan (X2), terhadap variabel dependent berupa Kinerja Pemasaran (Y). Sedangkan Inovasi Produk (Z) sebagai variabel intervening. maka dapat dibuat pengembangan model penelitian dengan kerangka pemikiran teoritis dibawah ini

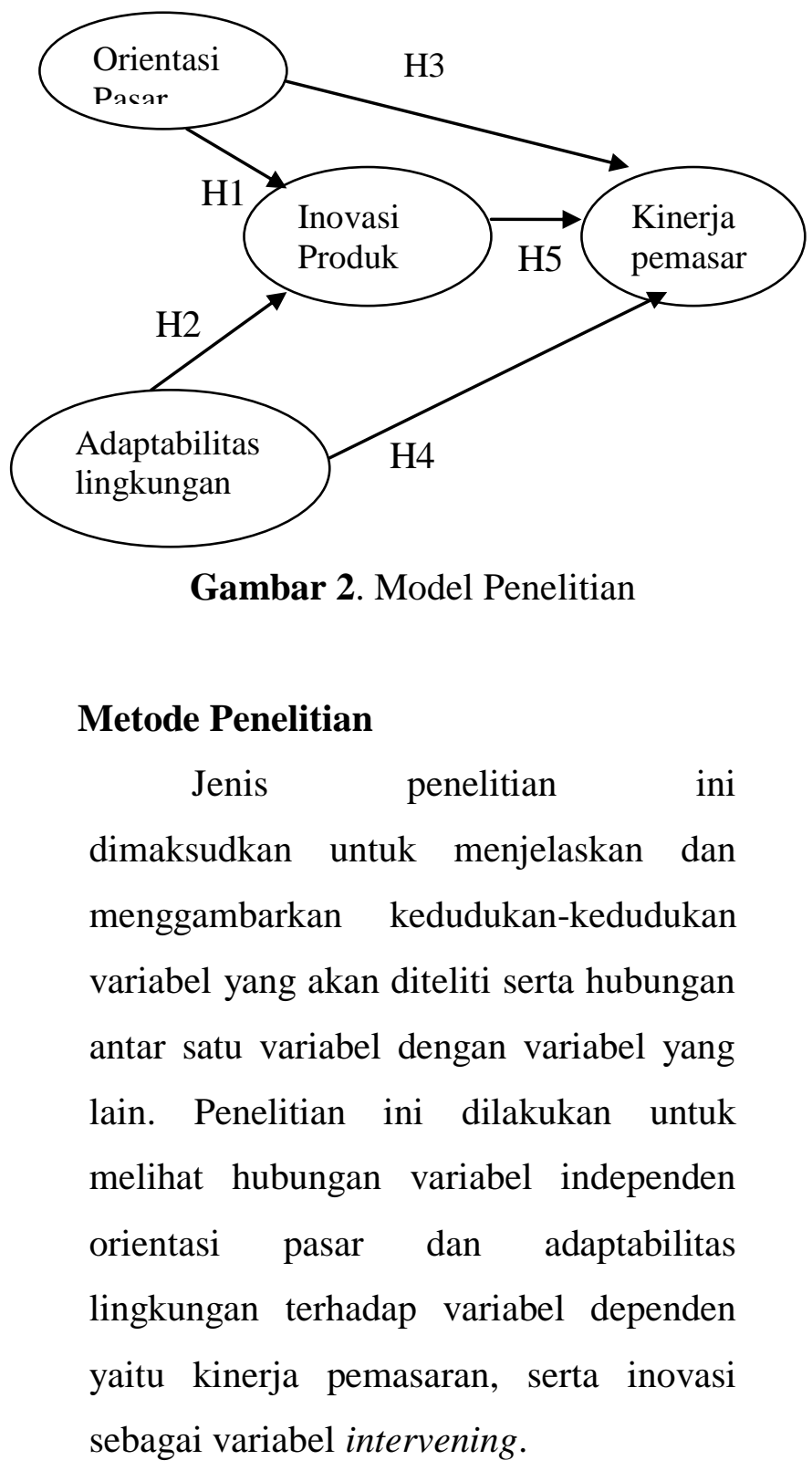

Gambar 2. Model Penelitian

\section{Metode Penelitian}

Jenis penelitian ini

dimaksudkan untuk menjelaskan dan menggambarkan kedudukan-kedudukan variabel yang akan diteliti serta hubungan antar satu variabel dengan variabel yang lain. Penelitian ini dilakukan untuk melihat hubungan variabel independen orientasi pasar dan adaptabilitas lingkungan terhadap variabel dependen yaitu kinerja pemasaran, serta inovasi sebagai variabel intervening.
Dalam penelitian kuantitatif, operasional variable digunakan sebagai upaya mengoperasionalkan sehingga jelas indikator sampai pada yang lebih teknis pada variabel yang dioperasionalkan. Operasionalisasi variabel pada penelitian ini dapat dilihat pada Tabel 1.

Tabel 1. Operasionalisasi Variabel

\begin{tabular}{ll}
\hline \multicolumn{1}{c}{ Variabel } & Skala \\
Orientasi Pasar $\left(\mathrm{X}_{1}\right)$ & Interval \\
Indikator : & \\
1. informasi keinginan pelanggan & \\
& $\left(\mathrm{X}_{1.1}\right)$ \\
pemenuhan keinginan & \\
2. pelanggan & $\left(\mathrm{X}_{1.2}\right)$ \\
3. pelayanan pelanggan $\left(\mathrm{X}_{1.3}\right)$ \\
mengetahui srategi pesaing \\
4. $\left(\mathrm{X}_{1.4}\right)$ \\
5. respon cepat kegiatan pesaing \\
\\
$\quad\left(\mathrm{X}_{1.5}\right)$
\end{tabular}

Adaptabilitas Lingkungan $\left(\mathrm{X}_{2}\right)$

Indikator :

1. Ketersediaan di alam / musim $\left(\mathrm{X}_{2.1}\right)$

2. Kekuatan pemasok $\left(X_{2.2}\right)$

3. Keberadaan pesaing $\left(\mathrm{X}_{2.3}\right)$

4. Kekuatan pembeli $\left(\mathrm{X}_{2.4}\right)$

Kinerja Pemasaran (Y)

Interval

Indikator :

Pencapaian target penjualan

1. $\left(\mathrm{Y}_{1}\right)$

2. Peningkatan omset penjualan $\left(\mathrm{Y}_{2}\right)$

3. Peningkatan profit penjualan $\left(\mathrm{Y}_{3}\right)$

Peningkatan Jumlah

4. pelanggan $\left(\mathrm{Y}_{4}\right)$

5. Perluasan pangsa pasar $\left(\mathrm{Y}_{5}\right)$

Inovasi Produk (Z)

Interval

Indikator :

1. Penciptaan produk baru $\left(\mathrm{Z}_{1}\right)$

2. Variasi produk $\left(Z_{2}\right)$

3. Pengemasan produk $\left(Z_{3}\right)$

4. Kontrol kualitas produk $\left(Z_{4}\right)$

Interval 
PROGRESS

Jurnal Pendidikan, Akuntansi dan Keuangan

Universitas Banten Jaya
Dalam penelitian ini populasi yang digunakan memiliki kriteria sebagai pelaku usaha baik pemilik maupun pengelola UMK durian di Kota Serang, Cilegon, Pandeglang, Lebak dan Kota Tangerang yang diperkirakan mencapai lebih dari 100 UMK, yang terdiri dari :

a. Produsen olahan makanan berbahan dasar durian.

b. Supplier dan Penjual buah durian bulatan.

c. Kafe, resto, dan kedai dengan menu utama durian

Adapun kriteria sampel penelitian ini yaitu para member Komunitas Pengusaha Durian se-Banten (KPDB) yang tercatat ada sekitar 70 UMK. KPDB ini bersekretariat di Jl. Saleh Baimin No.38 Cimuncang Kota Serang

Pengumpulan data dalam penelitian ini dilakukan dengan menyebarkan kuesioner kepada 70 pengusaha durian daerah Banten yang dilakukan secara online menggunakan tool google forms, disebar lewat grup whatsapp.

Dalam penelitian ini kuesioner dibuat dengan menggunakan pertanyaan tertutup dan terstruktur. Pengukuran variabel menggunakan skala interval menggunakan teknik Agree-Disagree Scale dimana adanya urutan skala 1 (Sangat Tidak Setuju) sampai dengan 10 (Sangat Setuju) serta semantik deferensial untuk semua variabel. Contoh untuk kategori pernyataan dengan jawaban sangat tidak setuju (STS) / sangat setuju (SS).

\section{Teknik Analisis}

Pada penelitian ini menggunakan analisa statistik deskriptif dan statistik inferensia. Statistik deskriptif adalah statistic yang digunakan untuk menganalisa data dengan cara mendeskrisikan atau menggambarkan data yang telah terkumpul sebagaimana adanya tanpa bermaksud membuat kesimpulan yang berlaku untuk umum atau generalisasi. Sedangkan statistik inferensia adalah teknik statistik yang digunakan untuk menganalisis data sampel dan hasilnya diberlakukan untuk populasi (Sugiyono, 2017). Dalam penelitian ini, terdapat 5 (lima) hipotesis yang berbeda. Sesuai dengan model yang dikembangkan dalam penelitian ini maka alat analisa data yang digunakan yaitu Structural Equation Modeling (SEM) dengan menggunakan Partial Least Square (PLS) versi 3.0 (SEM-PLS v 3.0).

Analisis statistik deskriptif ini dilakukan terhadap variabel-variabel penelitian yang digunakan yaitu orientasi pasar, adaptabilitas lingkungan, inovasi produk, dan kinerja pemasaran. Analisis ini dilakukan dengan menggunakan teknik analisis indeks untuk menggambarkan 
persepsi responden atas item-item pertanyaan yang diajukan.

Dengan menggunakan kriteria tiga kotak (Three-box Method), maka pengelompokan tanggapan responden berdasarkan batas-batas penelitian terhadap bagian-bagian yang dievaluasi dapat dikelompokan sebagai berikut :

Tabel 2. Batas Pengelompokan Jawaban Responden

\begin{tabular}{cc}
\hline Indeks & Keterangan \\
\hline $10,00-40,00$ & Rendah \\
$40,01-70,00$ & Sedang \\
$70,01-100,00$ & Tinggi \\
\hline
\end{tabular}

Sumber : Ferdinand (2014)

Tanggapan responden terhadap indikator-indikator orientasi pasar serta hasil perhitungan indeks pernyataan variabel orientasi pasar dalam kuesioner yang telah disebar disajikan pada :

Tabel 3. Deskripsi Indeks Orientasi Pasar

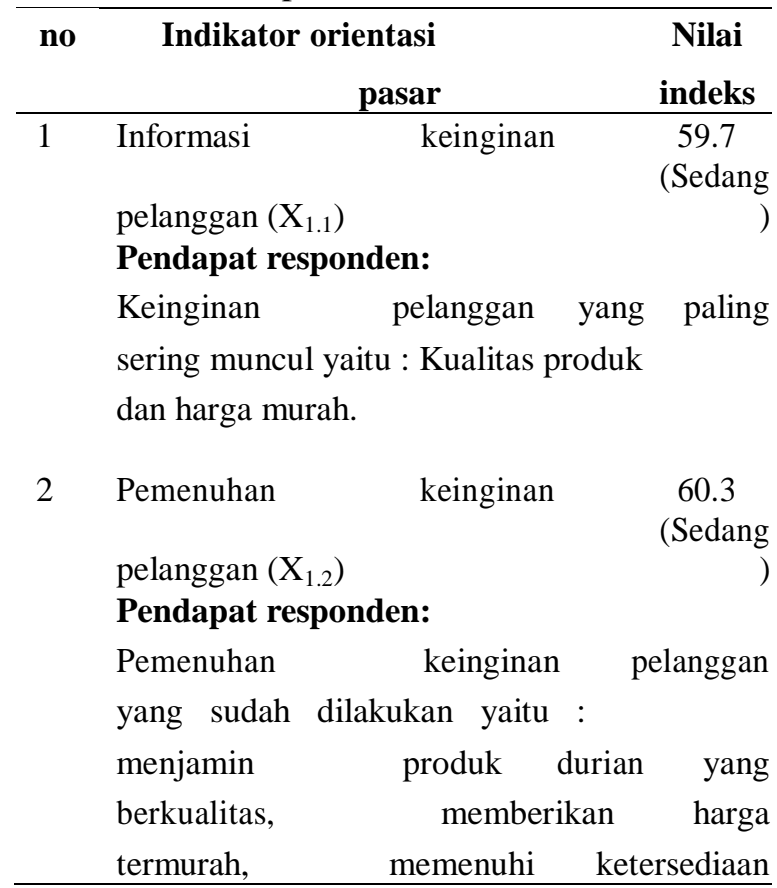

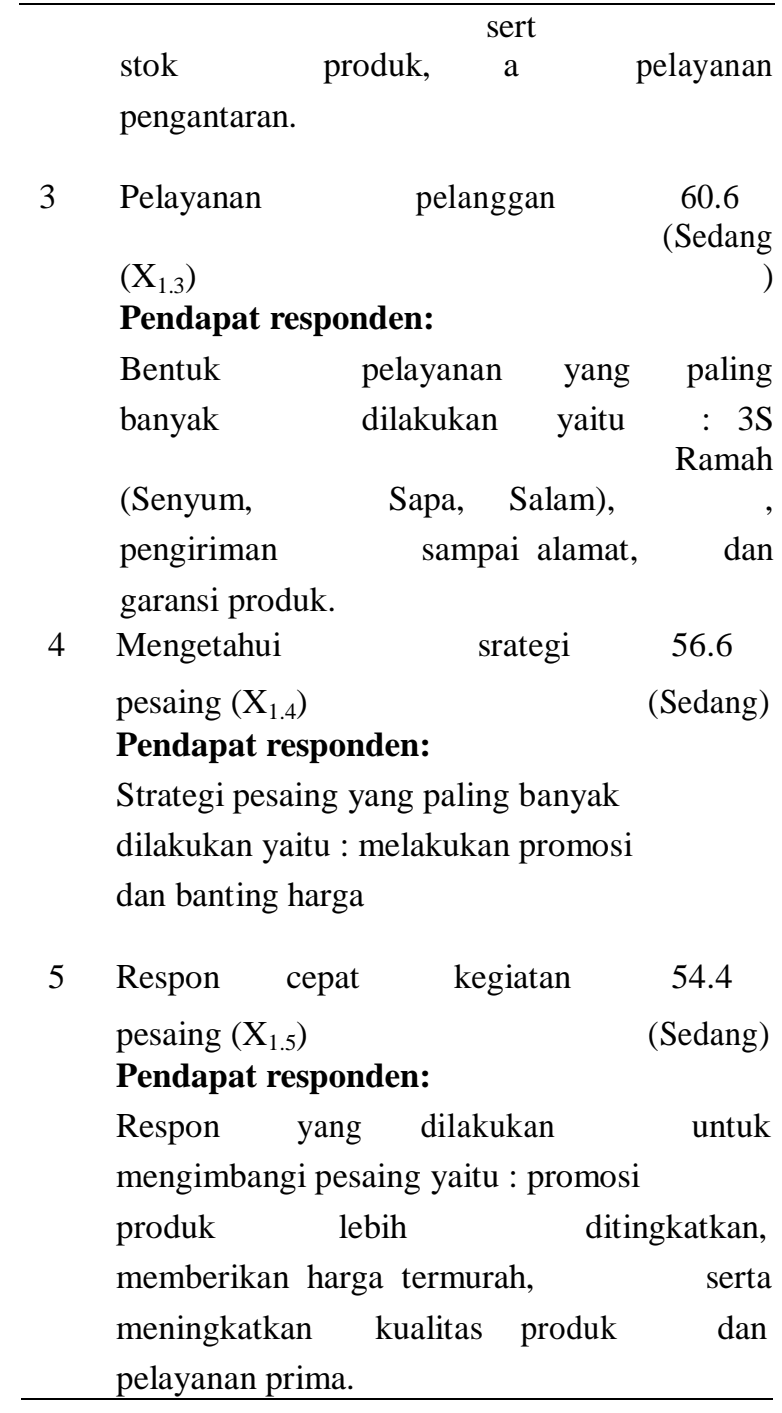

Tanggapan responden terhadap beberapa indikator adaptabilitas lingkungan serta hasil perhitungan indeks pernyataan variable adaptabilitas lingkungan dalam kuesioner yang telah disebar dan disajikan pada tabel 4.

Tabel 4. Deskripsi Indeks

Adaptabilitas Lingkungan

\begin{tabular}{clc} 
No & \multicolumn{1}{|c}{$\begin{array}{c}\text { Indikator Adaptabilitas } \\
\text { Lingkungan }\end{array}$} & $\begin{array}{c}\text { Nilai } \\
\text { Indeks }\end{array}$ \\
\hline 1 & Ketersediaan di alam / & 58.5 \\
& musim $\left(\mathrm{X}_{2.1}\right)$ & (Sedang) \\
& $\begin{array}{l}\text { Pendapat Responden: } \\
\text { strategi yang dilakukan apabila buah }\end{array}$ \\
\hline
\end{tabular}


durian sedang habis musim yaitu dengan melakukan stok barang sebanyak-banyaknya saat sedang panen dan mencari durian alternatif di daerah-daerah lain

2 Kekuatan pemasok $\left(\mathrm{X}_{2.2}\right)$ 56.9 (Sedang)

\section{Pendapat Responden:}

Pasokan stok barang didukung oleh supplier besar dengan jumlah rata-rata 7 pemasok

3 Keberadaan pesaing $\left(\mathrm{X}_{2.3}\right)$ 56.2 (Sedang)

\section{Pendapat Responden:}

Strategi yang dilakukan saat munculnya pesaing baru yaitu : menjaga pelanggan agar tetap setia dengan memberi harga spesial, kualitas produk dan kualitas layanan. Serta lebih gencar melakukan promosi

4 Kekuatan pembeli $\left(\mathrm{X}_{2.4}\right)$

\section{Pendapat Responden:} (Sedang)

Antisipasi kelemahan pembelian dilakukan dengan cara memberikan diskon harga disamping menjaga kualitas produk dan pelayanan

Tanggapan responden terhadap indikatorindikator kinerja pemasaran serta hasil perhitungan indeks pernyataan variabel kinerja pemasaran dalam kuesioner yang telah disebar disajikan pada Tabel 5.
Tabel 5. Deskripsi Indeks

Kinerja Pemasaran

\begin{tabular}{clc}
\hline No & \multicolumn{1}{c}{$\begin{array}{c}\text { Indikator Kinerja } \\
\text { Pemasaran }\end{array}$} & $\begin{array}{c}\text { Nilai } \\
\text { Indeks }\end{array}$ \\
\hline 1 & $\begin{array}{l}\text { Pencapaian target } \\
\text { penjualan }\left(\mathrm{Y}_{1}\right)\end{array}$ & $\begin{array}{c}54.3 \\
\text { (Sedang) }\end{array}$ \\
& $\begin{array}{l}\text { Pendapat Responden: } \\
\text { Pencapaian target penjualan paling }\end{array}$ \\
& $\begin{array}{l}\text { banyak di hari libur, weekend, dan saat } \\
\text { panen raya }\end{array}$ \\
2 & $\begin{array}{l}\text { Peningkatan omset } \\
\text { penjualan }\left(\mathrm{Y}_{2}\right)\end{array}$ & 54.4 \\
&
\end{tabular}

\section{Pendapat Responden:}

Peningkatan omset paling banyak di di hari libur, weekend, dan saat panen raya

3 Peningkatan profit

penjualan $\left(\mathrm{Y}_{3}\right)$

(Sedang)

Pendapat Responden:

Peningkatan profit paling banyak di hari libur, weekend, \& saat panen raya

Peningkatan jumlah

4 Pelanggan $\left(\mathrm{Y}_{4}\right)$

(Sedang)

\section{Pendapat Responden:}

Kisaran peningkatan jumlah pelanggan sekitar 20-30\% setiap tahunnya

Perluasan pangsa pasar

$5 \quad\left(\mathrm{Y}_{5}\right)$ (Sedang)

Pendapat Responden:

Pangsa pasar yang sudah dicapai antara lain : pelanggan ecer, kedai, restauran, hingga reseller

Tanggapan responden terhadap indikator-indikator inovasi produk serta hasil perhitungan indeks pernyataan variabel inovasi produk dalam kuesioner yang telah disebar disajikan pada Tabel 6 . 
Tabel 6. Deskripsi Indeks Inovasi Produk

\begin{tabular}{lll}
\hline No & $\begin{array}{c}\text { Indikator Inovasi } \\
\text { Produk }\end{array}$ & $\begin{array}{l}\text { Nilai } \\
\text { Indeks }\end{array}$ \\
\hline 1 & Penciptaan produk baru & 53.8 \\
& $\left(\mathrm{Z}_{1}\right)$ & (Sedang)
\end{tabular}

Pendapat Responden:

Produk inovasi yang dibuat dan belum ada di daerah pemasarannya yaitu produk-produk seperti : keripik durian, durian tanpa biji, sambal durian, durian bakar, popcorn durian, ubi lumer durian, es cincau durian

2

$$
\text { Variasi produk }\left(\mathrm{Z}_{2}\right)
$$

Pendapat Responden:

\section{5}

(Sedang)

Variasi produk yang dilakukan yaitu, dengan menambah variasi rasa, dan aneka topping terutama pada sop / minuman durian. Serta variasi bentuk, jumlah, isi dan warna.

Pengemasan produk

$\left(\mathrm{Z}_{3}\right)$

56.7

(Sedang)

\section{Pendapat Responden:}

Pengemasan produk durian yang banyak dilakukan yaitu dengan cara membeli produk, toples plastik, membuat vacuum (kedap udara) ada petunjuk penyajian sefta dengan menambahkan Nomor P-IRT

Kontrol kuatiltas produk 59.7

$\left(\mathrm{Z}_{4}\right)$

(Sedang)

\section{Pendapat Responden:}

Cara melakukan control kualitas produk yaitu dengan cek rasa dan aroma, serta menyimpan durian ke frizer agar lebih awet, serta menjaga suhu agar tetap beku dengan cara tidak sering buka tutup pintu frizer.

Analisa model pengukuran atau

outer model digunakan untuk memastikan bahwa measurement yang digunakan layak untuk dijadikan pengukuran (valid atau realiabel). Dari hasil input tabulasi data kuesioner dalam bentuk excel, kemudian diolah menggunakan program SmartPLS 3.0. Terlebih dahulu digambarkan model konstruk penelitiannya pada dimensi dan indikator. Maka, hubungan antara konstruk terhadap indikatornya dapat dilihat pada Gambar 3.

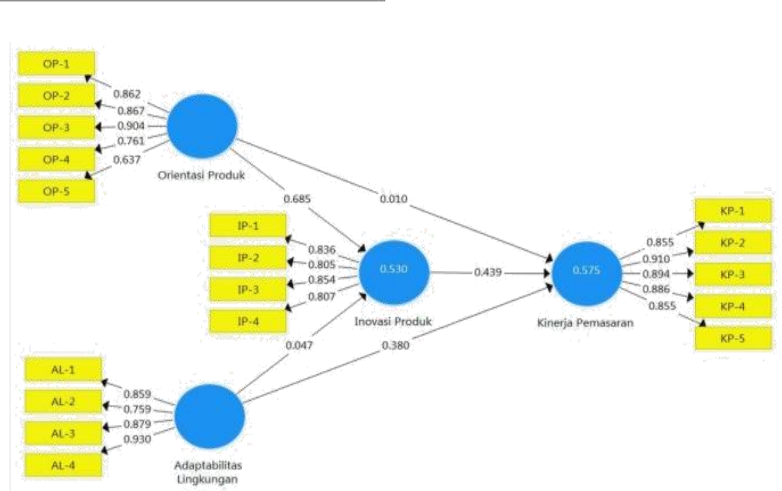

Gambar 3. Model Output Pengukuran

Convergent validity dari model pengukuran dengan refleksif indikator dinilai berdasarkan korelasi antara item score/component score yang diestimasi dengan Software PLS. Menurut Ghozali (2012), nilai loading faktor antara 0,5-0,6 dikatakan cukup dan sedang, sedangkan nilai loading faktor dikatakan tinggi jika berkorelasi lebih dari 0,70 dengan konstruk yang diukur. Oleh karena banyak kasus dalam loading antara 0,50,6 harus tetap dipertimbangakan untuk tetap dipertahankan.

Nilai construct reliability dan nilai average variance extracted (AVE) diperlihatkan dalam Tabel 7 dibawah ini. 
Tabel 7. Construct Reliability dan Validity

\begin{tabular}{ccccc}
\hline Konstruk & CA & Rho_A & CR & AVE \\
\hline $\begin{array}{c}\text { Orientasi } \\
\text { pasar } \\
\text { Adaptabilitas } \\
\text { lingkungan } \\
\text { Kinerja } \\
\text { Pemasaran } \\
\text { Inovasi } \\
\text { produk }\end{array}$ & 0.881 & 0.903 & 0.918 & 0.738 \\
& 0.966 & 0.847 & 0.896 & 0.682 \\
$C A=$ Cronbach's Alpha & 0.931 & 0.945 & 0.775 \\
$C R=$ Composite Reliability & & 0.905 & 0.660 \\
$A V E=$ & & & \\
\hline Average Variance Extracted (AVE) &
\end{tabular}

Berdasarkan Tabel 7 dijelaskan bahwa nilai Cronbach's alpha dan composite reliability yang dihasilkan dari setiap konstruk sangat baik yaitu memiliki nilai diatas 0.7 (Hair et al, 2014) sehingga dapat disimpulkan bahwa semua indikator konstruk adalah reliabel. Begitu pula dengan nilai AVE untuk setiap konstruk sangat baik yaitu memiliki nilai diatas 0.5 (Hair et al, 2014) sehingga dinyatakan valid. Berdasarkan hasil pengujian validitas dan reliabilitas yang telah diuraikan, dapat disimpulkan bahwa seluruh pertanyaan yang digunakan dalam penelitian layak digunakan sebagai alat ukur penelitian.

Tabel 8. Hasil dari Path Coefficients

\begin{tabular}{lcccccc}
\hline & $\begin{array}{c}\text { Original } \\
\text { Sample } \\
(\boldsymbol{O})\end{array}$ & $\begin{array}{c}\text { Sample } \\
\text { Mean } \\
(\boldsymbol{M})\end{array}$ & $\begin{array}{c}\text { Standard } \\
\text { Deviation }\end{array}$ & $\begin{array}{c}\boldsymbol{T} \\
\text { Statistics }\end{array}$ & $\begin{array}{c}\boldsymbol{P} \\
\text { Values }\end{array}$ & Keterangan \\
\hline $\begin{array}{l}\text { Orientasi Pasar } \\
\text { Kinerja Pemasaran } \\
\begin{array}{l}\text { Adaptabilitas } \\
\text { Lingkungan }\end{array}\end{array}$ & 0.010 & 0.037 & 0.250 & 0.039 & 0.969 & $\begin{array}{c}\mathbf{H}_{\mathbf{1}} \text { tidak } \\
\text { diterima }\end{array}$ \\
$\begin{array}{l}\text { Kinerja Pemasaran } \\
\text { Orientasi Pasar } \\
\text { Inovasi Produk }\end{array}$ & 0.380 & 0.350 & 0.257 & 1.480 & 0.139 & $\begin{array}{c}\mathbf{H}_{\mathbf{2}} \text { tidak } \\
\text { diterima }\end{array}$ \\
$\begin{array}{l}\text { Adaptabilitas } \\
\text { Lingkungan }\end{array}$ & 0.685 & 0.705 & 0.214 & 3.197 & 0.001 & $\begin{array}{c}\mathbf{H}_{\mathbf{3}} \\
\text { diterima } \\
\text { Inovasi Produk } \\
\text { Inovasi Produk }\end{array}$ \\
\begin{tabular}{l} 
Kinerja Pemasaran \\
\hline
\end{tabular} & 0.047 & 0.039 & 0.230 & 0.204 & 0.838 & $\begin{array}{l}\mathbf{H}_{\mathbf{4}} \text { tidak } \\
\text { diterima }\end{array}$ \\
\hline
\end{tabular}

Berdasarkan Tabel 8 diatas, menunjukkan bahwa dari ke-5 Hipotesis yang diajukan, terdapat 3 (tiga) Hipotesis tidak diterima, yaitu pada $\mathrm{H}_{1}, \mathrm{H}_{2}$ dan $\mathrm{H}_{4}$. Sedangkan $\mathrm{H}_{3}$ dan $\mathrm{H}_{5}$ diterima.
Hasil pengujian hipotesis dengan bootstrapping dari analisis SmartPLS adalah sebagai berikut :

Dalam melakukan uji hipotesis, keberterimaan hipotesis yang diajukan 
syaratnya nilai $\mathrm{T}$ statistik harus lebih

besar dari $\mathrm{T}$ tabel 1.984, dan $\mathrm{P}$ value harus lebih kecil dari nilai probabilitas 0.05 (Ferdinand, 2014). Sedangkan nilai original sample lebih besar dari 0 (nol) menunjukkan adanya keberpengaruhan positif terhadap hubungan antar variabel yang diukur.
Analisa pengaruh dilakukan

untuk menganalisis kekuatan

pengaruh antar variabel baik pengaruh yang langsung, tidak langsung, dan pengaruh totalnya (Ferdinand, 2011). Hasil pengujian indirect effects dapat dilihat dalam Tabel 9 dibawah ini :

Tabel 9. Pengujian Indirect Effects

\begin{tabular}{lcccccc}
\hline & $\begin{array}{c}\text { Original } \\
\text { Sample } \\
(\mathbf{O})\end{array}$ & $\begin{array}{c}\text { Sample } \\
\text { Mean } \\
(\mathbf{M})\end{array}$ & $\begin{array}{c}\text { Standard } \\
\text { Deviation }\end{array}$ & $\begin{array}{c}\text { T } \\
\text { Statistics }\end{array}$ & $\begin{array}{c}\text { P } \\
\text { Values }\end{array}$ & Keterangan \\
\hline $\begin{array}{l}\text { Orientasi Pasar } \rightarrow \\
\text { Inovasi produk }\end{array}$ & 0.300 & 0.318 & 0.146 & 2.057 & 0.040 & $\begin{array}{c}\text { Dapat } \\
\text { memediasi }\end{array}$ \\
$\begin{array}{l}\text { Kinerja Pemasaran } \\
\text { Adaptabilitas }\end{array}$ & & & & & & \\
$\begin{array}{l}\text { Lingkungan } \\
\text { Inovasi Produk } \\
\text { Kinerja Pemasaran }\end{array}$ & 0.021 & 0.020 & 0.106 & 0.194 & 0.846 & $\begin{array}{c}\text { Tidak } \\
\text { dapat } \\
\text { memediasi }\end{array}$ \\
\hline
\end{tabular}

Sama seperti pengujian hipotesis, bahwa syaratnya nilai $\mathrm{T}$ statistik harus lebih besar dari T tabel 1.984, dan $\mathrm{P}$ value harus lebih kecil dari nilai probabilitas 0.05 (Ferdinand, 2014). Sedangkan nilai original sample lebih besar dari 0 (nol) menunjukkan adanya keberpengaruhan positif terhadap hubungan antar variabel yang diukur.

Berdasarkan Tabel 9 diatas, menunjukkan bahwa variabel inovasi produk dapat memoderasi variabel orientasi pasar terhadap kinerja

\section{Pengaruh Orientasi pasar Terhadap} Kinerja Pemasaran (HI)

Berdasarkan pada pengolahan data untuk menguji hipotesis 1, hasilnya menunjukkan bahwa orientasi pasar tidak berpengaruh positif terhadap kinerja pemasaran. Hal ini berarti bahwa dengan meningkatnya orientasi pasar, belum tentu dapat meningkatkan kinerja pemasaran pada UMK Durian. Besar dari 0 (nol) menunjukkan adanya keberpengaruhan positif terhadap hubungan antar variabel yang diukur.

Hasil penelitian ini selaras dengan penelitian sebelumnya yang dilakukan 
oleh Anshar (2016), Haryani (2015), dan Setyawati (2013) bahwa orientasi pasar belum dapat mempengaruhi kinerja pemasaran. Penelitian ini pula sangat bertentangan dengan penelitian yang dilakukan oleh Dharmana (2017) \& Ida Tri (2015) yang menyatakan bahwa terdapat pengaruh yang signifikan antara orientasi pasar terhadap kinerja pemasaran.

Fenomena di lapangan menunjukkan bahwa penerapan orientasi pasar yang diantaranya informasi dan pemenuhan keinginan pelanggan, pelayanan pelanggan, serta penerapan dan respon cepat terhadap pesaing masih belum dapat meningkatkan kinerja pemasaran pada pelaku UMK durian. Dalam menggaet pelanggan, pengusaha memberikan harga yang murah kepada konsumen dibawah harga pasar, dengan strategi "untung kecil yang penting lancar" menjadi hal yang biasa tanpa memperhitungkan biaya operasional yang tinggi, seperti sewa tempat, biaya karyawan, barang yang reject dan busuk akibat penyimpanan dan lama tak terjual. Sehingga dengan adanya ini, maka profit penjualan pun akan tergerus, keuntungan menjadi tidak seberapa meskipun omset penjualannya tinggi.

\section{PengaruhAdaptibilitasLingkungan}

\section{Terhadap Kinerja Pmesaran (H2)}

Dari pengolahan data uji hipotes 2, dapat diketahui bahwa adaptabilitas lingkungan tidak berpengaruh positif terhadap kinerja pemasaran. Hal ini berarti bahwa dengan meningkatnya adaptabilitas terhadap lingkungan, belum tentu dapat meningkatkan kinerja pemasaran pada UMK Durian. Hasil penelitian ini tidak sejalan dengan yang dilakukan oleh Charlina, dkk (2016) dan Sendhang (2012) bahwa faktor lingkungan dapat mempengaruhi kinerja pemasaran.

Dalam berbisnis durian, kendala yang paling besar terdapat pada faktor lingkungan. Durian merupakan salah satu buah musiman yang tidak selalu tersedia sepanjang tahun. Saat musim panen raya tiba, stok durian yang sangat melimpah ini mengakibatkan harga durian pun menjadi sangat murah. Tetapi saat musim durian telah habis, terjadi kelangkaan stok dimana-mana, meskipun ada saja di beberapa daerah yang tersedia namun tidak akan mencukupi semua permintaan pasar. Alhasil harga durian melonjak tajam ke angka yang fantastis. Kendala selanjutnya yaitu adanya persaingan bisnis yang tergolong ketat, baik itu persaingan dalam menggaet para petani (stok barang), serta persaingan dalam 
merebut pasar. Tentunya untuk mengungguli para pesaing, maka pebisnis yang memiliki modal besar yang akan menang. Tidak semua kalangan UMK dapat memiliki kemampuan modal yang bagus. Dengan adanya beberapa faktor lingkungan diatas itulah sehingga menghasilkan efek domino selanjutnya pada faktor kemampuan daya beli masyarakat yang semakin berkurang.

Pada kondisi lingkungan (musim) yang tidak memungkinkan ini, beberapa UMK mulai beralih berdagang buahbuahan lain, atau berdagang menu makanan olahan lainnya. Artinya, pemilik atau pengelola UMK tidak terpatok sama sekali dengan buah durian agar kinerja pemasaran tidak terlalu turun secara drastis.

Didasari oleh fenomena diatas maka peningkatan adaptabilitas terhadap lingkungan pemasaran seperti upaya mengatasi pasokan saat musim habis, pasokan dari distributor, pesaing baru, dan kelemahan pembelian, masih belum dapat meningkatkan kinerja pemasaran secara signifikan pada UMK durian.

\section{Kesimpulan}

Berdasarkan dari hasil penelitian yang dilakukan, dapat disimpulkan bahwa:

1. Orientasi pasar tidak berpengaruh signifikan terhadap peningkatan kinerja pemasaran pada UMK durian di daerah Banten.

2. Adaptabilitas lingkungan tidak berpengaruh signifikan terhadap peningkatan kinerja pemasaran pada UMK Durian di daerah Banten.

3. Orientasi pasar berpengaruh signifikan terhadap kegiatan inovasi produk pada UMK durian di daerah Banten.

4. Adaptabilitas lingkungan tidak berpengaruh signifikan terhadap kegiatan inovasi produk pada UMK Durian di daerah Banten.

5. Adaptabilitas lingkungan tidak berpengaruh signifikan terhadap kegiatan inovasi produk pada UMK Durian di daerah Banten.

\section{Saran}

Beberapa saran yang diajukan untuk penelitian selanjutnya seperti :

1. Sasaran UMK yang diteliti ada baiknya sejenis, misalkan UMK buah durian atau UMK produk olahan durian.

2. Diperlukan variabel penelitian yang lebih meluas, misalnya seperti varibel kreativitas produk ataupun inovasi layanan. 


\section{DAFTAR PUSTAKA}

Charlina et al, (2016). Strategi Pasar Sebagai Pemediasi Antara Lingkungan Pemasaran Dengan Kinerja Pemasaran Pada PT. BPR Prisma Dana Amurang. Jurnal EMB A Vol.4 No.1 Maret 2016, Hal. 1340-1354.

Dharmana \& Bayu. (2017). Peran Inovasi Produk Memediasi Orientasi Pasar Terhadap Kinerja Pemasaran. EJurnal Manajemen Unud, Vol. 6, No. 8, 2017: 4361-4390.

Ferdinand, Augusty. (2014). Metode Penelitian Manajemen, Semarang. Badan Penerbit Universitas Diponegoro.

Haryani. (2015). Orientasi Pasar, Orientasi Kewirausahaan,

Kapabilitas Pemasaran dan Kinerja Pemasaran. Jurnal Aplikasi Manajemen (JAM) Vol 13 No 4, 2015 Hal. 653-661.

Hasan, Ali. (2013). Marketing dan KasusKasus Pilihan. Yogyakarta. CAPS (Center For Academic Publishing Service).

Janti \& Sri. (2013).Model Kinerja Pemasaran Usaha Kecil dan Menengah (UKM) di Jawa Tengah. Jurnal Ilmiah Dinamika Ekonomi dan Bisnis Vol. 1 No. 1 April 2013 Hal. 56-68.

Khamidah. (2005). Analisis Pengaruh Faktor Lingkungan Terhadap Inovasi Produk dan Kreativitas Strategi Pemasaran Terhadap
Kinerja Pemasaran (Studi pada Perusahaan Kerajinan Keramik di Bantul, Yogyakarta). Jurnal Sains Pemasaran Indonesia. Vol. IV No. 03 Hal 231-246.

Kotler, Philip dan Armstrong G. (2014). Principles of Marketing. Edisi 15: Pearson Education.

Sendhang.(2012). Analisis Pengaruh Lingkungan Industri Terhadap Strategi Pemasaran dan Dampaknya Terhadap Kinerja Pemasaran( Studi Pada Usaha Kecil Kerajinan Kulit Tanggulangin). Jurnal Administrasi Bisnis Volume I Nomer 1 September 2012 Hal 7283.

Setyawati \& Harini. (2013).

Pengaruh Orientasi

Kewirausahaan Dan Orientasi Pasar Terhadap Kinerja Perusahaan Melalui Keunggulan Bersaing dan Persepsi Ketidakpastian Lingkungan Sebagai Prediksi Variabel Moderasi (Survey pada UMK Perdagangan di Kabupaten Kebumen). Jurnal Fokus Bisnis, Volume 12, No 02, Hal. 20-32.

Sutarno. (2012). Serba-Serbi Manajemen Bisnis. Yogyakarta: Graha Ilmu.

Tjiptono, Fandy. (2015). dkk. Strategi Pemasaran. Edisi IV. Yogyakarta: Andi Offset.

Uncles, Mark. (2005). Marketing Metrics: A Can of Worm or the path to englighment. Journal of Brand Management. Vol 12 No 6. 
PROGRESS

Jurnal Pendidikan, Akuntansi dan Keuangan

Universitas Banten Jaya
Vol 2 No. 2, Agustus 2019

E-ISSN 2622-7037 |P-ISSN 2623-0763 